\title{
Bioactive Lipids in Stem Cell Differentiation
}

\author{
Erhard Bieberich and Guanghu Wang \\ Georgia Health Sciences University \\ U.S.A.
}

\section{Introduction}

Bioactive lipids are lipids with cell signaling functions. In the last two decades, they have become increasingly important in many fields of biology. They are the main diffusible mediators of inflammatory responses in tissues and regulate the polarity of cellular membranes. They are also critical for cell fate decisions during stem cell differentiation by inducing apoptosis or sustaining cell survival and polarity. The bioactive lipids discussed here belong to the classes of phospho- and sphingolipids. Mainly three different types of lipids and their function in stem cell differentiation will be reviewed in detail: phophatidylinositols (PIPs), lysophospholipids and eicosanoids, and the sphingolipid ceramide and its derivative sphingosine-1-phosphate (S1P).

\section{Biological Function of bioactive lipids in stem cell differentiation}

\subsection{Phosphatidylinositols}

The phosphatidylinositols $\mathrm{PI}(3,4) \mathrm{P} 2$ and $\mathrm{PI}(3,4,5) \mathrm{P} 3$ generated by class I phosphatidyinositol-3-kinase (PI3K) upon induction of tyrosine receptor kinases or Gprotein coupled receptors (GPCRs) are known to be the major activators of the Akt/PKB cell signaling pathway for cell survival and differentiation (Callihan et al., 2011; Frebel \&Wiese, 2006; Layden et al., 2010; Paling et al., 2004; Storm et al., 2007; Umehara et al., 2007). The phosphatase and tensin homolog deleted on chromosome 10 (PTEN) is a lipid phosphatase that catalyzes the hydrolysis of PIP3 to PIP2, which leads to inactivation of the Akt/PKB cell signaling pathway and loss of pluripotency in stem cells (Groszer et al., 2001; Korkaya et al., 2009; Otaegi et al., 2006). PTEN is a tumor suppressor mutated in many types of cancer and it is critical for the controlled growth of embryonic tissue and ES cells.

PTEN converts PIP3 into PIP2 (Fig. 1). Since PIP3 activates the Akt/PKB cell signaling pathway, thus PTEN catalyzing PIP3 hydrolysis is a negative regulator of Akt/PKB. Consistent with this function, deletion of PTEN activates Akt/PKB-dependent cell signaling pathways (Groszer et al., 2001). PTEN mutations are often found in human cancers such as glioblastoma, prostate cancer, and breast cancer. Loss of function of this tumor suppressor gene results in the up-regulation of the Akt/PKB-to- $\beta$-catenin pathway (Fig. $2 \mathrm{~A}$ ) (Korkaya et al., 2009). Akt/PKB phosphorylates and therefore, inactivates glycogen synthase-3 $\beta$ (GSK$3 \beta$ ), a protein kinase in the Wnt signaling pathway that phosphorylates $\beta$-catenin (Doble \&Woodgett, 2003; Ikeda et al., 2000; van Noort et al., 2002). The oncogene $\beta$-catenin is an important adhesion protein and transcription factor for genes involved in proliferation. When phosphorylated by GSK-3 $\beta, \beta$-catenin (in a protein complex with adenomatous 
polyposis coli or APC) is proteolytically degraded and thus, adhesion lost and proliferation reduced. Consistent with this function, deletion of $\beta$-catenin results in loss of pluripotency and early embryonic death of the respective knockout mouse (Haegel et al., 1995). Likewise, deletion of PTEN results in increased $\beta$-catenin levels and increased pluripotency or malignancy (Groszer et al., 2001). Therefore, the PTEN vs. PI3K-to-Akt/PKB antagonism is interesting in two biological contexts with respect to stem cell differentiation: maintenance of pluripotent stem cells and tumorigenesis of cancer stem cells. In the first context, inhibition of PTEN, activation of PI3K and Akt/PKB, or inhibition of GSK-3 $\beta$ will be useful to maintain pluripotent ES cells. In the second context, activation of PTEN, inhibition of PI3K and Akt/PKB, or activation of GSK-3 $\beta$ may be a useful strategy to eliminate cancer stem cells.

In the cultivation process of ES cells, elevated expression of the transcription factors Oct-4 and Nanog is essential for maintenance of pluripotency (Bhattacharya et al., 2003; Sato et al., 2004). It has been shown that two cell signaling pathways are critical for this regulation: the janus kinase/signal transducer and activator of transcription 3 (Jak/Stat3) and the Akt/PKB signaling pathways (Fig. 2A) (Kelly et al., 2011; Paling et al., 2004). In the cultivation of mouse ES cells, the most important growth factor activating Stat 3 and Akt/PKB is LIF (leukemia inhibitory factor), an interleukin 6 class cytokine binding to LIF receptor a (LIFRa) (Cartwright et al., 2005; Niwa et al., 1998; Okita \&Yamanaka, 2006; Schuringa et al., 2002; Takao et al., 2007). In vitro, LIF is added to the medium when cultivating undifferentiated mouse ES cells on feeder fibroblasts and in feeder-free culture. In vivo, LIF is generated by the trophoectoderm from where it penetrates the inner cell mass, the source of pluripotent ES cells in the pre-implantation embryo. In human ES cells, the role of LIF as "guardian" of pluripotency is taken over by fibroblast growth factor (FGF) (Lanner \&Rossant, 2010; Li et al., 2007) (Fig. 2A). Binding of FGF-2 to the FGF receptor 2 (FGFR2) activates similar cell signaling pathways in human ES cells as stimulated by LIF in mouse ES cells: Jak/Stat3, mitogen-activated protein kinase (MAPK), and Akt/PKB (Lanner \&Rossant, 2010; Li et al., 2007). However, FGFR-dependent signaling is very diverse and it depends on individual receptor protein complexes which specific response is elicited by FGF. For example, in mouse ES cells, FGF-2 is used to maintain the multipotent neuroprogenitor stage and to prevent further neuronal differentiation. In human ES cells, supplementation of the serum-free cell culture medium with FGF-2 is critical to prevent apoptosis and to maintain pluripotency.

The role of lipids as the key factors in the PI3K-to-Akt/PKB-to- $\beta$-catenin cell signaling pathway is obvious since phosphatidylinositols (PIPs) are lipids by provenance. Unfortunately, PIPs are not applicable as exogenous factors that can be simply added to stem cell media since these lipids are part of an intracellular cell signaling cascade not easily accessible to the outside of the cell. However, there are other lipid-regulated pathways that are dependent on the activation of cell surface receptors, which is of tremendous advantage if one attempts to use lipids as exogenously added growth or differentiation factors (see section 2.2). The two receptors involved in maintenance of pluripotency, LIFRa and FGFR2 are both tyrosine receptor kinases which are not directly activated by lipids, although indirect regulation by so-called "lipid rafts" has been discussed (see section 2.4) (Lee et al., 2010b; Yanagisawa et al., 2004b, 2005).

In addition to using natural lipids as ligands, stem cell differentiation can also be modulated by pharmacologic reagents that are either lipid analogs, inhibitors of enzymes in lipid 


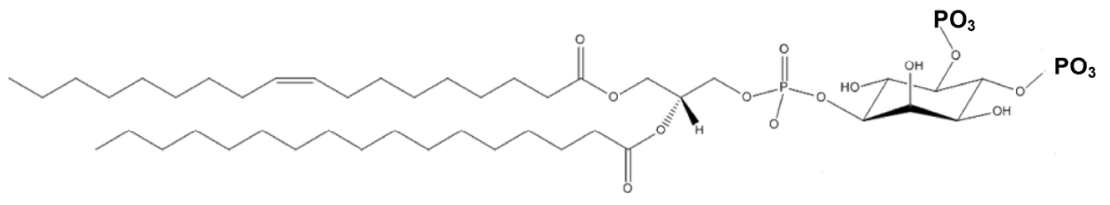

Phosphatidylinositol (4,5)-bisphosphate PIP2

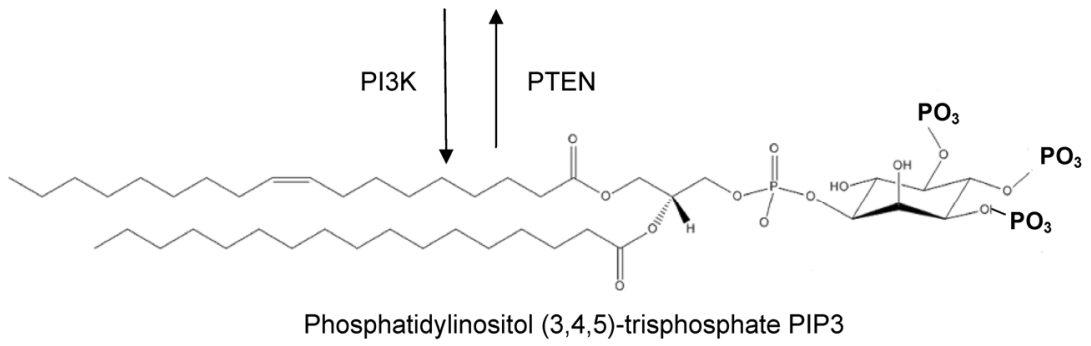

Fig. 1. Metabolism of phosphatidylinositols in the PI3K-to-Akt/PKB cells signaling pathway for ES cell pluripotency. PI3K, phosphatidylinositol 3-kinase; PTEN, phosphatase and tensin homolog deleted on chromosome 10

metabolism, or drugs targeting downstream effectors of lipid-regulated cell signaling pathways. Two drugs that are inhibitors of protein kinases in the LIFRa and FGFR2 pathways have been tested on their effect on pluripotency: LY294002 and indirubin-3monoxime, two inhibitors specific for PI3K and GSK-3 $\beta$, respectively (Chen et al., 2006; Chen et al., 2000; Ding \&Schultz, 2004; Ding et al., 2003; Lyssiotis et al., 2011; Otaegi et al., 2006; Paling et al., 2004; Sato et al., 2004). The PI3K inhibitor LY294002 has been shown to reduce the capacity of mouse and human ES cells to self-renew and to undergo subsequent steps of lineage specification and differentiation (Paling et al., 2004). These effects are likely to involve differentiation stage-specific (contextual) other cell signaling pathways downstream (or parallel) to the PI3K-to-Akt/PKB signaling axis. While it may not be desired to interfere with ES cell pluripotency, LY294002 and other PI3K and Akt/PKB inhibitors are currently tested for cancer treatment, in particular for targeting cancer stem cells (Bleau et al., 2009; Plo et al., 1999). If one desires to sustain self-renewal of ES cells, GSK-3 $\beta$ inhibitors such as indirubin-3-monoxime or BIO are attractive candidates. BIO has been successfully used to maintain pluripotency in human ES cells (Sato et al., 2004). Additional effectors targeting GSK-3 $\beta$ are synthetic agonists of the Wnt receptor Frizzled, however, their use in stem cell differentiation is not yet sufficiently investigated (Lyssiotis et al., 2011).

Interestingly, inhibitors of the mitogen activated protein kinase (MAPK) pathway such as the MAPK kinase (MEK) inhibitor PD98059 have been used with mouse ES cells to promote self-renewal or pluripotency (Buehr \&Smith, 2003; Li et al., 2007). This appears paradoxical since LIFRa as well as FGFR2 are known to activate MAPK, which suggests that activation of MAPK is involved in pluripotency. However, only transient MAPK activation to promote G1 re-entry is useful for self-renewal while prolonged activation will promote differentiation (Fig. 2B). Therefore, a combination of LIF with the MAPK-kinase (MEK) inhibitor PD95059 activating PI3K-to-Akt/PKB while inhibiting MAPK signaling has been successfully used to promote pluripotency in mouse ES cells, but also to enhance the 


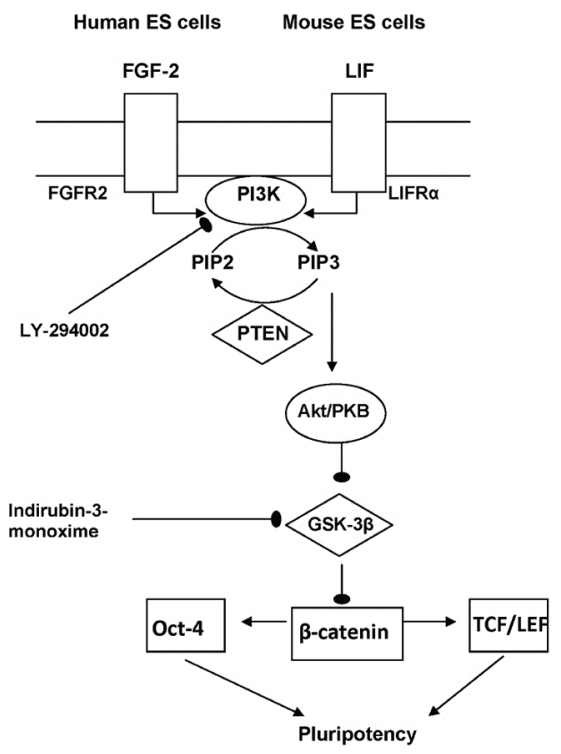

A

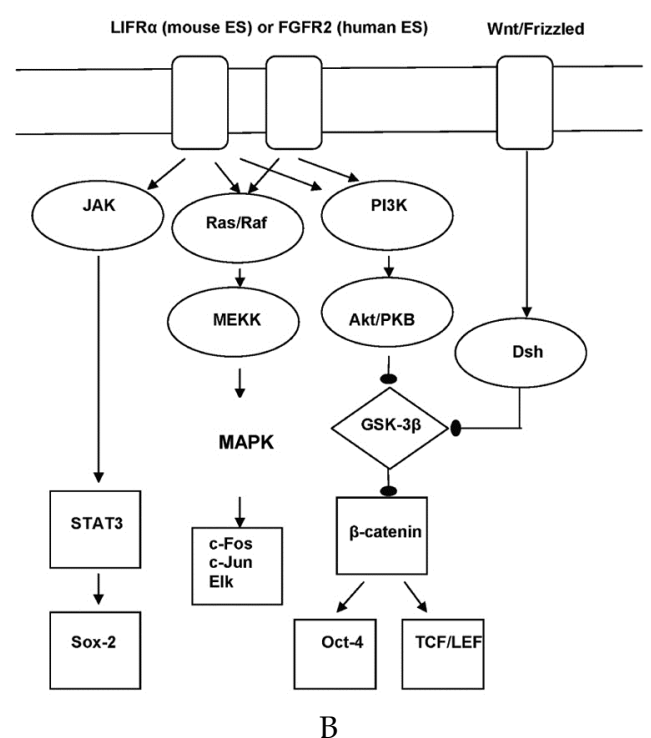

Fig. 2. Cell signaling pathways for ES cell pluripotency. Elliptic circles label enzymes that promote pluripotency, while diamonds label enzymes that reduce pluripotency and promote differentiation. MAPK shows both, pro-pluripotency or pro-differentiation activity in human or mouse ES cells, respectively.

generation of induced pluripotent stem (iPS) cells (Li et al., 2007; Lyssiotis et al., 2011). The situation in human ES cells, however, is different. In contrast to mouse ES cells, inhibition of the MAPK cell signaling pathway reduces the potential of undifferentiated human ES cells to self-renew, indicating that FGFR2-mediated activation of Ras/Raf-to-MEK-to MAPK is critical for human ES cell pluripotency (Ding et al., 2010). A similar role has been found for Bmp4, which promotes pluripotency in mouse and differentiation in human ES cells (Bouhon et al., 2005; Zeng et al., 2004; Zhang et al., 2010). It is quite possible that this difference depends on which other pathways for pluripotency are co-activated such as Jak/Stat3 in mouse or Activin in human ES cells. Bioactive lipids are important in that they co-regulate several cell signaling pathways critical for pluripotency and differentiation of ES cells, in particular MAPK and PI3K downstream of ClassA/Rhodopsin-like GPCRs, which will be discussed in the next section.

\subsection{Lysophospholipids and eicosanoids}

Lysophospholipids (LPLs) are lipids generated by hydrolytic cleavage of fatty acid from glycerophospholipids, which is catalyzed by phospholipases. Distinct phospholipases cleave off either one of the two (PLA1 and PLA2) or both (PLB) fatty acid residues, or they cleave off the phosphate-containing head group (PLC) or the alcohol (PLD) (Gardell et al., 2006; Hla et al., 2001; Hla et al., 2000; Lin et al., 2010; Meyer zu Heringdorf \&Jakobs, 2007; Okudaira et al., 2010; Radeff-Huang et al., 2004; Tigyi \&Parrill, 2003; Ye et al., 2002). PLA2 generates arachidonic acid, the precursor for the generation of eicosanoids, a group of inflammatory mediators including prostaglandins and leukotrienes (Funk, 2001; Jenkins et 
al., 2009; Khanapure et al., 2007; Lambeau \&Gelb, 2008; Szefel et al., 2011; Wymann \&Schneiter, 2008). Similar to the PLD reaction, lysophospholipase D or autotaxin generates lysophosphatidic acid (LPA) from lysophosphatidylcholine (Nakanaga et al., 2010; Okudaira et al., 2010; Samadi et al., 2011). LPA receptors are critical in cell proliferation and tumorigenesis and have recently been shown to promote proliferation of human neural precursor cells (Callihan et al., 2011; Hurst et al., 2008; Lin et al., 2010; Pebay et al., 2007; Pebay et al., 2005; Pitson \&Pebay, 2009).

Arachidonic acid, generated by PLA2 from phospholipids such as phosphatidylcholine (Fig. $3 \mathrm{~A}$ ) is converted to a variety of pro-inflammotory eicosanoids among which prostaglandins, thromboxanes, and leukotrienes are the most important signaling lipids (Fig. 3B). The effect of eicosanoids on ES cells is not well understood and research is mostly limited to results with mouse ES cells. Interestingly, lysophospholipids such as LPA and eicosanoids such as prostaglandin E2 (PGE2) appear to activate similar downstream cell signaling pathways, mainly the PI3K-to-Akt/PKB, MAPK, and Wnt/GSK-3 $\beta$ pathways (Callihan et al., 2011; Goessling et al., 2009; Logan et al., 2007; North et al., 2007; Pebay et al., 2007; Pitson \&Pebay, 2009; Yun et al., 2009). In contrast to LIFRa or FGFR2, however, stimulation of Akt/PKB by PGE2 has not been reported to sustain pluripotency, but is rather anti-apoptotic/cell protective and promotes stem cell proliferation. This may not be surprising since generation and conversion of arachidonic acid is often a response to hypoxic insults, which can damage mitochondria and induce apoptosis. Notably, inhibition of eicosanoid biosynthesis reduces the potential of mouse and human ES cells to self-renew, indicating a role of eicosanoids in stem cell maintenance or pluripotency (Yanes et al., 2010). Thromboxane has not been described to play a role in stem cell differentiation, maybe because its main function is rather confined to platelet aggregation. In contrast, prostacyclin, a similar eicosanoid in platelet aggregation has been shown to promote cardiogenic differentiation from human ES

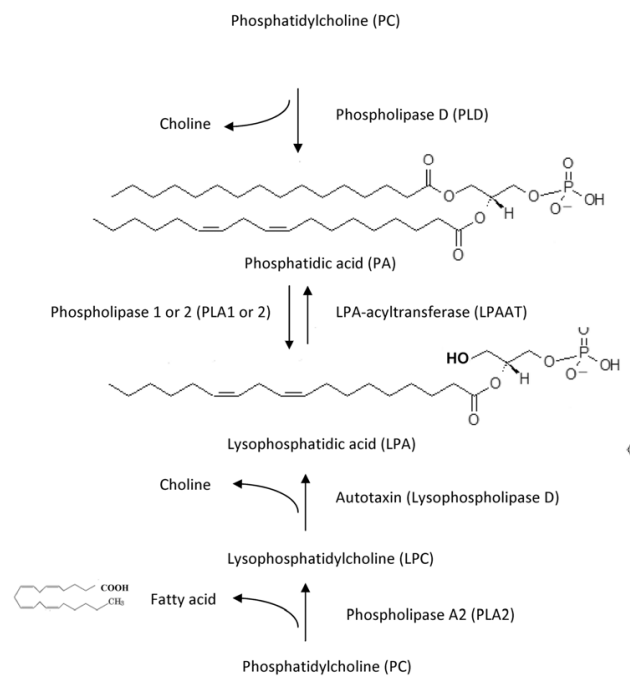

A

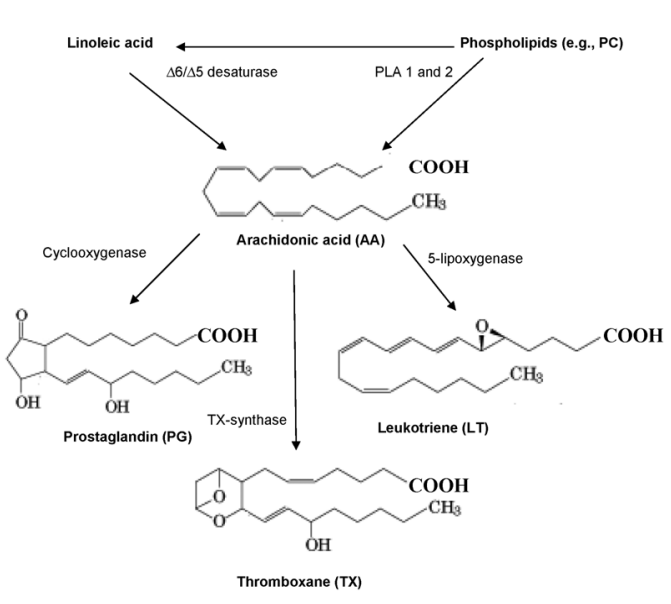

B

Fig. 3. Biosynthesis pathways in lysoposphatidic acid (LPA) and eicosanoid metabolism 
cells (Chillar et al., 2010; Xu et al., 2008). In addition to prostacyclin, leukotriene of the LTD4 type has been used in several studies to promote proliferation and cardiovascular differentiation of mouse ES cells (Finkensieper et al., 2010; Funk, 2001; Kim et al., 2010).

The effect of prostaglandins and other eicosanoids on ES cells is worth discussing in an important aspect of human health care. Inhibitors of cyclooxygenase 2 (Cox-2), the enzyme critical for PGE2 production, are taken by nearly everyone to ease up head ache, back pain, and inflammation. The Cox-2 inhibitor aspirin is one of the most successfully administered drugs world-wide. A recent study on the negative effect of non-steroidal anti-inflammatory drugs (NSAIDs) such as aspirin on the differentiation of human ES cells suggests that one has to be careful with the use of NSAIDs when human ES cells are to be transplanted for heart tissue repair (Chillar et al., 2010). These observations suggest that eicosanoids are important in cardiogenic/cardiovascular differentiation of ES cells.

The eicosanoid as well as lysophospholipid receptors belong to the family of Class A Rhodopsin-like GPCRs (Callihan et al., 2011; Hla et al., 2001; Kostenis, 2004; Lin et al., 2010; Pitson \&Pebay, 2009; Radeff-Huang et al., 2004). They mediate the activation of downstream cell signaling pathways through different types of GTPases, mainly Gi, Gq, and G12/13,

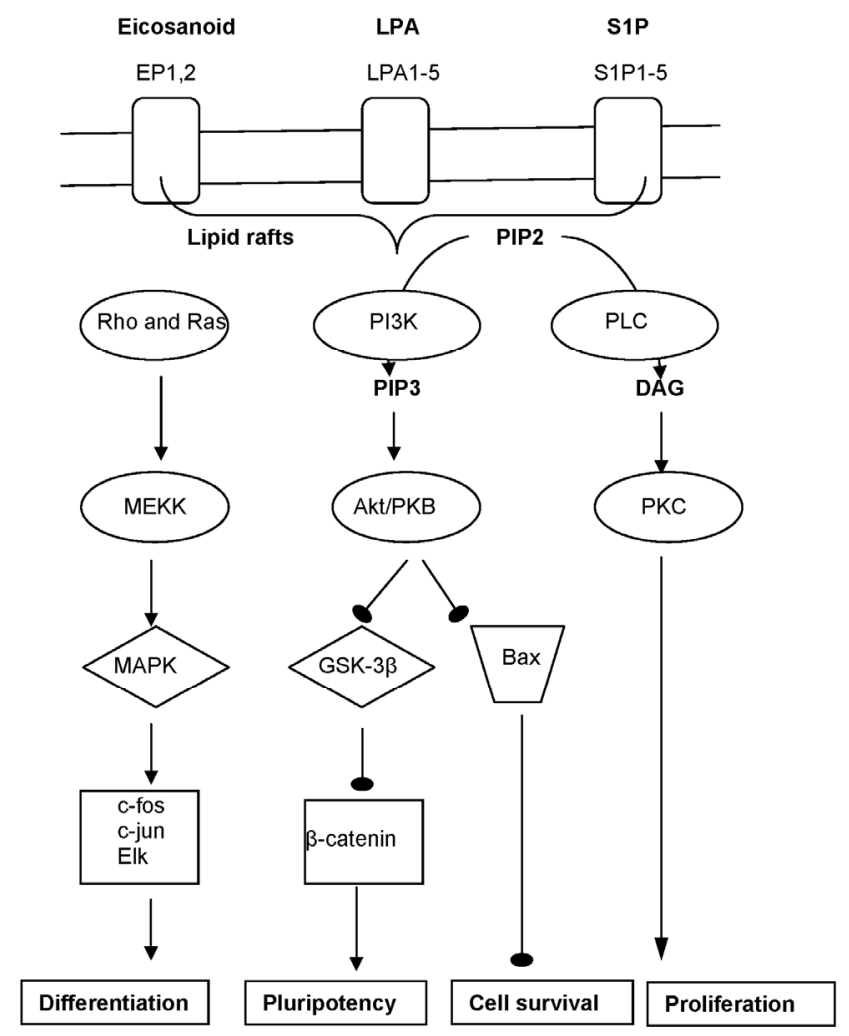

Fig. 4. GPCR-dependent cell signaling pathways with similar function for ES cell pluripotency and differentiation. DAG, diacylglycerol; PLC, phospholipase C; EP, eicosanoid receptor. 
acting upon PI3K-to-Akt/PKB (Gi), Ras-to-ERK (Gi, Gq) Rho (G12/13), and PLC-to-PKC $(\mathrm{Gq})$ cell signaling pathways for pluripotency and cell survival (Akt/PKB), proliferation (Rho and PKC), and differentiation/specification (MAPK) pathways (Fig. 4). Hence, combinations of particular cell signaling lipids with cytokines or growth factors such as LIF or FGF-2 activating similar effectors have been found to be useful in directing stem cell fate toward pluripotency, proliferation, or differentiation, respectively (Hurst et al., 2008; Kilkenny et al., 2003; Layden et al., 2010; Pebay et al., 2007; Radeff-Huang et al., 2004). There are five GPCRs for each LPA and sphingosine-1-phosphate (S1P) expressed in mouse and human ES cells.

\subsection{Ceramide and sphingosine-1-phosphate}

Sphingolipids are acyl (fatty acid) derivatives of the amino alcohol sphingosine. They encompass sphingosine, ceramide, and ceramide derivatives such as sphingomyelin, ceramide-1-phosphate, S1P, and glycosphingolipids (Fig. 5A for structures) (Bartke \&Hannun, 2009; Chalfant \&Spiegel, 2005; Chen et al., 2010; Futerman \&Hannun, 2004; Hannun et al., 2001; Hannun \&Obeid, 2002, 2008; Lebman \&Spiegel, 2008; Merrill et al., 1997; Spiegel \&Milstien, 2003; Strub et al., 2010; Takabe et al., 2008). Important biological functions of sphingolipids are cell signaling for inflammation, apoptosis, cell cycle regulation, and autophagy (Bartke \&Hannun, 2009; Basu \&Kolesnick, 1998; Bieberich, 2004, 2008a; Futerman \&Hannun, 2004; Gulbins \&Kolesnick, 2003; Haimovitz-Friedman et al., 1997; Hannun \&Obeid, 2008; Morales et al., 2007). Most recently, particular sphingolipids have also been implicated in ES cell differentiation and cell polarity (Bieberich, 2004, 2008a, b, 2010; Bieberich et al., 2003; Bieberich et al., 2001; Bieberich et al., 2004; Gardell et al., 2006; Goldman et al., 1984; Harada et al., 2004; Hurst et al., 2008; Jung et al., 2009; Pebay et al., 2007; Pebay et al., 2005; Pitson \&Pebay, 2009; Salli et al., 2009; Walter et al., 2007; Wang et al., 2008a; Wong et al., 2007; Yanagisawa et al., 2004a). Ceramide has been shown to induce apoptosis specifically in residual pluripotent stem (rPS) cells that cause teratomas (stem cellderived tumors) after stem cell transplantation. S1P has been found to promote oligodendrocyte differentiation (see section 3.2. for discussion).

Ceramide is the precursor of all bioactive sphingolipids. It is synthesized in three different metabolic pathways. Figure 5B shows that sphingolipid metabolism is integrated into phospholipid (i.e., PC), one carbon unit (i.e., choline), fatty acid (i.e., palmitoyl CoA for de novo biosynthesis and other fatty acids in the salvage pathway), and amino acid (i.e., serine in de novo biosynthesis) metabolism (Bartke \&Hannun, 2009; Bieberich, 2004, 2008a; Chen et al., 2010; Futerman \&Hannun, 2004; Futerman \&Riezman, 2005; Gault et al., 2010; Hannun et al., 2001; Luberto \&Hannun, 1999). In cell cultures, plenty of these precursors are provided in the medium, which may not necessarily reproduce the metabolic situation of stem cells or other cell types in vivo. Recently, our group has found that neural crest-derived stem or progenitor cells are sensitive to alcohol due to ethanol-induced elevation of ceramide and induction of apoptosis (Wang \&Bieberich, 2010). Apoptosis can be prevented by supplementing the medium with CDP-choline, This effect can be explained by providing excess of substrate required to drive conversion of ceramide to SM using the interconnection of the Kennedy pathway for phospholipid biosynthesis and the SM cycle (Fig. 5B). Choline can also be replenished from the one carbon unit metabolism, which establishes the interconnection of sphingolipid metabolism with this metabolic pathway.

The fatty acid metabolism interconnects with sphingolipid biosynthesis twice, in the de novo and salvage pathways. The de novo pathway uses palmitoyl CoA and serine for a 
condensation reaction that is the first step in ceramide biosynthesis. Since serine is used as the second substrate, de novo biosynthesis ties into the amino acid metabolism as well. The salvage pathway uses a variety of activated fatty acids for re-attachment to sphingosine (Fig. 5B). While supply with precursors for lipid metabolism may not be critical in vitro, specialized tissues or cells such as astrocytes providing nutrients and metabolic precursors to neurons or neural stem cells in vivo maybe more sensitive toward lipid imbalances as observed in fetal alcohol syndrome and Alzheimer's disease (Adibhatla \&Hatcher, 2008; Cutler et al., 2004; De Vito et al., 2000; Hirabayashi \&Furuya, 2008; Jana et al., 2009; Jana \&Pahan, 2010; Muscoli et al., 2010; Riboni et al., 2002; Satoi et al., 2005; Wang et al., 2008b). In particular, neural stem cells are confined to distinct morphological cell complexes which tightly control the interaction with other cells and therefore, comprise "metabolic niches" that may control supply with metabolic precursors and lipid cell signaling factors.

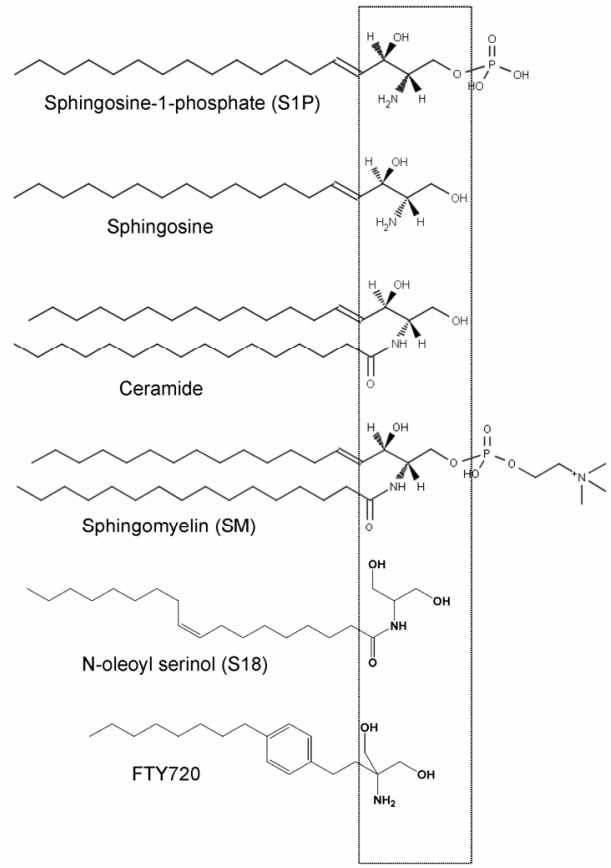

A

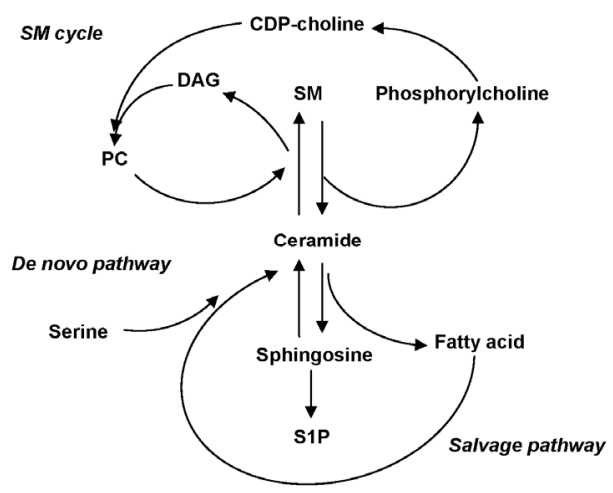

B

Fig. 5. Structures of ceramide precursors and derivatives with cell signaling function and interconnection of ceramide metabolism with other lipid and amino acid metabolism. Noleoyl serinol (S18) or FTY720 are analogues of ceramide or S1P, respectively. Box shows common structural motif.

Regulation of sphingolipid metabolism by its interconnection with other lipid metabolic pathways has a direct impact on lipid-dependent cell signaling. Ceramide is the precursor of $\mathrm{S1P}$, which is a ligand for five distinct S1P receptors (S1P1-5) on the cell surface and also binding partner/co-factor for at least three intracellular proteins, histone deacetylase 1 and 2 
(HDAC 1 and 2) in the nucleus, the E3 ubiquitin ligase TRAF2, and prohibitin in the mitochondria (Alvarez et al., 2010; Callihan et al., 2011; Hait et al., 2009; Hait et al., 2006; Hurst et al., 2008; Pitson \&Pebay, 2009; Radeff-Huang et al., 2004; Sanchez \&Hla, 2004; Spiegel \&Kolesnick, 2002; Strub et al., 2011) . The effect of intracellular S1P on stem cell differentiation is not known. However, there is solid experimental evidence that S1P has profound effects on ES cells and ES cell-derived neural progenitors via S1P receptors, which will be discussed in section 3.2 .

\subsection{Terpenoids, sterols, glycosphingolipids, and lipid rafts}

The previous sections discussed bioactive lipids that are known to act through lipid receptors or binding proteins. There are many more lipids that regulate cell signaling pathways through a mechanism known as "lipid rafts" or "lipid microdomains" (Bieberich, 2008a; Lee et al., 2010b; Lingwood \&Simons, 2010; Miljan \&Bremer, 2002; Ohanian \&Ohanian, 2001; Yanagisawa et al., 2005). Lipid rafts are areas in the cell membrane (or intracellular membranes) that emerge from the self-assembly of lipids in an ordered structure. They are believed to show high affinity to specific cell signaling proteins such as growth factor or cytokine receptors, which leads to clustering and activation of these receptors. Therefore, bioactive lipids can affect stem cell differentiation in two different ways: direct interaction with lipid receptors such as GPCRs and lipid raft-dependent activation of growth factor or cytokine receptors such as LIFRa or FGFR2 (Bieberich, 2008a; Bryant et al., 2009; Gutierrez \&Brandan, 2010; Lee et al., 2010b; Yanagisawa et al., 2005). Lipids that form rafts are sphingomyelin, cholesterol, and glycosphingolipids. In addition, signal transduction proteins such as Ras can be modified with fatty acids (palmitoylation) or terpenoids (farnesylation, geranylation) and glycophosphatidylinositol (GPI anchor), which tremendously increases membrane binding and raft association (Levental et al., 2010; Lingwood \&Simons, 2010; Resh, 2004; Roy et al., 2005). It has been shown that particular glycosphingolipids termed gangliosides can regulate ES cell differentiation by the activation of FGFR2 and other receptors in lipid rafts (Bieberich, 2004; Yanagisawa et al., 2005). An example for this mechanism is the corrective activity of the ganglioside GM1 on the effect of the fungus toxin fumonisin B1, which causes neural tube defects by inhibiting sphingolipid biosynthesis (Gelineau-van Waes et al., 2005; Marasas et al., 2004). It has also been demonstrated that the activity of sonic hedgehog, a morphogen critical for germ layer formation is functionally dependent on palmitoylation and modification with cholesterol (Gofflot et al., 2003; Guy, 2000; Incardona \&Roelink, 2000; Karpen et al., 2001; Kelley et al., 1996; Lewis et al., 2001; Li et al., 2006). Inhibition of cholesterol biosynthesis with statins leads to aberrant embryo development. Although these are impressive examples of the effect of lipid modification and lipid raft formation on stem cell differentiation and embryo development, it is presently not known how to specifically utilize this mechanism in controlling the differentiation of ES cells. It is also not clear, which differentiation potential cholesterol has besides being critical for lipid raft formation. There is a plethora of steroid hormones such as estrogen or progesterone that are bioactive lipids activating nuclear receptors critical for embryo development. Progesterone is a particularly curious case since it is added to most of the supplements (e.g., N2, B27) found in defined media used for the in vitro maintenance and differentiation of ES cells. The use of this and other bioactive and synthetic lipids for the in vitro differentiation of ES cells will be discussed in the following section. 


\section{Bioactive lipids and their use for in vitro differentiation of embryonic stem cells}

\subsection{Induction of apoptosis in teratoma-forming stem cells by ceramide analogs}

The reliability and safety of current stem cell differentiation protocols is still a matter of controversy. Many studies have shown that even when using similar protocols for the in vitro differentiation of ES cells, transplantation can lead to the formation of teratomas (Baker, 2009; Bieberich, 2008b; Blum \&Benvenisty, 2008; Fong et al., 2010; Fujikawa et al., 2005; Lee et al., 2009; Vogel, 2005; Wang et al., 2010). Teratomas are stem cell-derived tumors that are fatal if they grow in the brain or heart. Teratomas may arise from any type of pluripotent cells, including induced pluripotent stem (iPS) cells. Therefore, they are a major safety concern, in particular when using larger numbers of ES or iPS cell-derived cells. Our studies have shown that teratomas arise from a particular type of residual pluripotent stem (rPS) cells that maintain the expression of the pluripotency transcription factor Oct-4 and fail to differentiate or undergo apoptosis (Bieberich, 2008a, b, 2010; Bieberich et al., 2003; Bieberich et al., 2004). However, we have also found that they coexpress prostate apoptosis response 4 (PAR-4), a protein that sensitizes cells toward ceramide-induced apoptosis. Using a water-soluble ceramide analog termed N-oleoyl serinol or S18, which was for the first time synthesized in our laboratory, we were able to rid stem cells grafts of teratoma-forming rPS cells (Bieberich et al., 2002; Bieberich et al., 2000). We have shown that $S 18$ promotes binding of atypical PKC (aPKC) to PAR-4, which inhibits the aPKC-activated NF-KB cell survival pathway and induces apoptosis in rPS cells (Bieberich, 2008a; Krishnamurthy et al., 2007; Wang et al., 2009; Wang et al., 2005). These cells are eliminated because they are sensitive to S18. Neural progenitor cells will survive and undergo further differentiation because they show no or only low level expression of PAR-4.

\subsection{Induction of oligodendrocyte differentiation by S1P and S1P analogs}

It has been shown that S1P and the S1P prodrug analog FTY720 promote cell survival and differentiation of primary cultures of oligodendroglial precursor cells (OPCs) (Bieberich, 2010; Coelho et al., 2010; Jung et al., 2007; Miron et al., 2008a; Saini et al., 2005). We have found that teratoma-forming rPS cells do not express the S1P receptor S1P1, which makes them vulnerable to ceramide or S18-induced apoptosis (Bieberich, 2008b, 2010; Bieberich et al., 2004). In contrast, ES cell-derived neural progenitor cells express S1P1. Our studies have shown that in the presence of S18 and FTY720, neural progenitor cells will survive and undergo oligodendroglial differentiation because they are insensitive to S18 (PAR-4 is not expressed). At the same time, OPC differentiation is promoted by FTY720 or S1P (S1P1 is expressed). Implantation of S18 and FTY720-treated neural progenitors does not result in teratoma formation and leads to integration of the grafted cells into highly myelinated areas of the brain such as the corpus callosum (Bieberich, 2010). Therefore, a combined treatment with ceramide analogs and S1P analogs or S1P receptor agonists is a promising strategy to control ES cell differentiation toward OPCs that are useful for treatment of de- or dysmelination diseases such as multiple sclerosis. Interestingly, the addition of S1P analogs to the ceramide analog S18 resulted in a shift of predominantly neuronal differentiation (as promoted by S18 alone) of ES cells toward oligodendroglial lineage, which is an impressive example for the impact of bioactive lipids on stem cell differentiation. 


\subsection{Synthetic lipids as small molecular effectors for ES cell differentiation}

The use of defined media supplemented with small molecule effectors that control the in vitro differentiation of stem cells is a promising strategy to generate transplantable progenitor cells that have not been in contact with animal-derived products such as serum. Currently, there are more than twenty compounds available that specifically induce differentiation of ES cells toward progenitors of bone, heart, muscle, or brain tissue. Although most of these compounds are not considered bioactive lipids because they are synthetic drugs not found in biological organisms, almost all of them are lipids with respect to their chemical structure. One of the first synthetic lipids used a small molecule effector for ES cell differentiation is a bioactive lipid with critical function in brain development: retinoic acid (Dinsmore et al., 1996; Guan et al., 2001; Hu et al., 2009; Jiang et al., 2010; Lee et al., 2010a; Liour et al., 2006; Mayer-Proschel et al., 1997; Mummery et al., 1990; Murashov et al., 2005; Osakada \&Takahashi, 2011; Plachta et al., 2004). Mouse and human ES cells respond to a brief exposure to retinoic acid by accelerating differentiation into motoneurons, interneurons, and even oligendendrocytes when combined with specific growth factors such as FGF-2 or platelet-derived growth factor (PDGF). Another bioactive lipid used for in vitro differentiation of mouse and human ES cells, in particular toward oligodendroglial lineage is thyroid hormone (T3) (Glaser et al., 2007; Kang et al., 2007).

In addition to these naturally occurring lipids, synthetic lipids have been isolated from chemical libraries using various bioassays for ES cell differentiation. Indirubin-3-oxime type compounds for maintenance of pluripotency have already been discussed in section 1 . A more detailed discussion of these small molecule effectors can be found in the following articles (Ding et al., 2003; Lyssiotis et al., 2011; Zhu et al., 2010). The advantage of these compounds emerges from their lipid-like structure, which allows for penetration of the blood brain barrier. Provided that toxicity issues do not prevent the use of these compounds in vivo, bioactive and synthetic lipids are likely to develop into powerful pharmacologic drugs that can be used for in vitro differentiation of ES or iPS cells and then after transplantation, for further treatment of the patient to enhance the in vivo differentiation of the grafted cells. One of the first drugs with this dual potential of in vitro and in vivo use is FTY720 (Bieberich, 2010; Coelho et al., 2007; Lee et al., 2010a; Miron et al., 2008a; Miron et al., 2008b; Napoli, 2000). It is quite expectable that many of these "dual use" drugs will play an important role in the clinical application of ES and iPS cells.

\section{Conclusions and perspectives}

The goal of this chapter was to review current knowledge on bioactive lipids in embryonic stem cell differentiation. One of the important results of this analysis is the insight into the interconnection between lipid metabolism and signaling function. Unlike most proteins, lipids can be converted into derivatives that either complement or antagonize each other's cell signaling function. For example, conversion of PC to LPA and eisosanoids has similar effects on enhancing pluripotency. On the other hand, conversion of ceramide to S1P can have opposite functions, in particular with respect to apoptosis and survival of pluripotent stem cells. Another important insight is that most bioactive lipids cooperate with cytokine and growth factor receptors providing the possibility to combine these factors with the respective lipids in defined media for controlled stem cell differentiation. For example, FGF2 can be combined with the ceramide analog S18 to promote neuronal differentiation, or with S18 and FTY720 to enhance specification to oligodendroglial lineage. This provides the 
opportunity to generate bioactive lipids or lipid analogs that can be applied for in vitro differentiation of stem cells and then for further treatment of the patient who has received the stem cell graft. These "dual use" bioactive lipids will be of tremendous value for the therapeutic application of stem cells.

\section{Acknowledgment}

The authors acknowledge support in part by the NIH (R01AG034389 to EB), March of Dimes Foundation (MOD 6-FY08-322 to EB), a Scientist Training Grant from the Georgia Health Sciences University (to GW), and a Scientist Development grant from the American Heart Association (to GW). We also thank the Institute of Molecular Medicine and Genetics (under directorship of Dr. Lin Mei) for institutional support.

\section{References}

Adibhatla, R.M. \& Hatcher, J.F. (2008). Altered lipid metabolism in brain injury and disorders. Subcell Biochem, Vol.49241-268.

Alvarez, S.E.; Harikumar, K.B.; Hait, N.C.; Allegood, J.; Strub, G.M.; Kim, E.Y.; Maceyka, M.; Jiang, H.; Luo, C.; Kordula, T.; Milstien, S. \& Spiegel, S. (2010). Sphingosine-1phosphate is a missing cofactor for the E3 ubiquitin ligase TRAF2. Nature, Vol.465, No.7301, pp.1084-1088.

Baker, M. (2009). Stem cells: Fast and furious. Nature, Vol.458, No.7241, pp.962-965.

Bartke, N. \& Hannun, Y.A. (2009). Bioactive sphingolipids: metabolism and function. J Lipid Res, Vol.50 SupplS91-96.

Basu, S. \& Kolesnick, R. (1998). Stress signals for apoptosis: ceramide and c-Jun kinase. Oncogene, Vol.17, No.25, pp.3277-3285.

Bhattacharya, B.; Miura, T.; Brandenberg, R.; Mejido, J.; Luo, Y.; Yang, A.X.; Joshi, B.H.; Irene, G.; Thies, R.S.; Amit, M.; Lyons, I.; Condie, B.G.; Iskovitz-Eldor, J.; Rao, M.S. \& Puri, R.K. (2003). Gene Expression in Human Embryonic Stem Cell Lines: Unique Molecular Signature. Blood.

Bieberich, E. (2004). Integration of glycosphingolipid metabolism and cell-fate decisions in cancer and stem cells: review and hypothesis. Glycoconj J, Vol.21, No.6, pp.315-327.

Bieberich, E. (2008a). Ceramide signaling in cancer and stem cells. Future Lipidol, Vol.3, No.3, pp.273-300.

Bieberich, E. (2008b). Smart drugs for smarter stem cells: making SENSe (sphingolipidenhanced neural stem cells) of ceramide. Neurosignals, Vol.16, No.2-3, pp.124-139.

Bieberich, E. (2010). There is More to a Lipid than just Being a Fat: Sphingolipid-Guided Differentiation of Oligodendroglial Lineage from Embryonic Stem Cells. Neurochem Res.

Bieberich, E.; Hu, B.; Silva, J.; MacKinnon, S.; Yu, R.K.; Fillmore, H.; Broaddus, W.C. \& Ottenbrite, R.M. (2002). Synthesis and characterization of novel ceramide analogs for induction of apoptosis in human cancer cells. Cancer Lett, Vol.181, No.1, pp.5564.

Bieberich, E.; Kawaguchi, T. \& Yu, R.K. (2000). N-acylated serinol is a novel ceramide mimic inducing apoptosis in neuroblastoma cells. J Biol Chem, Vol.275, No.1, pp.177-181.

Bieberich, E.; MacKinnon, S.; Silva, J.; Noggle, S. \& Condie, B.G. (2003). Regulation of cell death in mitotic neural progenitor cells by asymmetric distribution of prostate 
apoptosis response 4 (PAR-4) and simultaneous elevation of endogenous ceramide. J Cell Biol, Vol.162, No.3, pp.469-479.

Bieberich, E.; MacKinnon, S.; Silva, J. \& Yu, R.K. (2001). Regulation of apoptosis during neuronal differentiation by ceramide and b-series complex gangliosides. $J$ Biol Chem, Vol.276, No.48, pp.44396-44404.

Bieberich, E.; Silva, J.; Wang, G.; Krishnamurthy, K. \& Condie, B.G. (2004). Selective apoptosis of pluripotent mouse and human stem cells by novel ceramide analogues prevents teratoma formation and enriches for neural precursors in ES cell-derived neural transplants. J Cell Biol, Vol.167, No.4, pp.723-734.

Bleau, A.M.; Hambardzumyan, D.; Ozawa, T.; Fomchenko, E.I.; Huse, J.T.; Brennan, C.W. \& Holland, E.C. (2009). PTEN/PI3K/Akt pathway regulates the side population phenotype and ABCG2 activity in glioma tumor stem-like cells. Cell Stem Cell, Vol.4, No.3, pp.226-235.

Blum, B. \& Benvenisty, N. (2008). The tumorigenicity of human embryonic stem cells. Adv Cancer Res, Vol.100133-158.

Bouhon, I.A.; Kato, H.; Chandran, S. \& Allen, N.D. (2005). Neural differentiation of mouse embryonic stem cells in chemically defined medium. Brain Res Bull, Vol.68, No.1-2, pp.62-75.

Bryant, M.R.; Marta, C.B.; Kim, F.S. \& Bansal, R. (2009). Phosphorylation and lipid raft association of fibroblast growth factor receptor-2 in oligodendrocytes. Glia, Vol.57, No.9, pp.935-946.

Buehr, M. \& Smith, A. (2003). Genesis of embryonic stem cells. Philos Trans R Soc Lond B Biol Sci, Vol.358, No.1436, pp.1397-1402; discussion 1402.

Callihan, P.; Mumaw, J.; Machacek, D.W.; Stice, S.L. \& Hooks, S.B. (2011). Regulation of stem cell pluripotency and differentiation by $G$ protein coupled receptors. Pharmacol Ther, Vol.129, No.3, pp.290-306.

Cartwright, P.; McLean, C.; Sheppard, A.; Rivett, D.; Jones, K. \& Dalton, S. (2005). LIF/STAT3 controls ES cell self-renewal and pluripotency by a Myc-dependent mechanism. Development, Vol.132, No.5, pp.885-896.

Chalfant, C.E. \& Spiegel, S. (2005). Sphingosine 1-phosphate and ceramide 1-phosphate: expanding roles in cell signaling. J Cell Sci, Vol.118, No.Pt 20, pp.4605-4612.

Chen, S.; Do, J.T.; Zhang, Q.; Yao, S.; Yan, F.; Peters, E.C.; Scholer, H.R.; Schultz, P.G. \& Ding, S. (2006). Self-renewal of embryonic stem cells by a small molecule. Proc Natl Acad Sci U S A, Vol.103, No.46, pp.17266-17271.

Chen, Y.; Li, X.; Eswarakumar, V.P.; Seger, R. \& Lonai, P. (2000). Fibroblast growth factor (FGF) signaling through PI 3-kinase and Akt/PKB is required for embryoid body differentiation. Oncogene, Vol.19, No.33, pp.3750-3756.

Chen, Y.; Liu, Y.; Sullards, M.C. \& Merrill, A.H., Jr. (2010). An introduction to sphingolipid metabolism and analysis by new technologies. Neuromolecular Med, Vol.12, No.4, pp.306-319.

Chillar, A.; So, S.P.; Ruan, C.H.; Shelat, H.; Geng, Y.J. \& Ruan, K.H. (2010). A profile of NSAID-targeted arachidonic acid metabolisms in human embryonic stem cells (hESCs): Implication of the negative effects of NSAIDs on heart tissue regeneration. Int J Cardiol.

Coelho, R.P.; Payne, S.G.; Bittman, R.; Spiegel, S. \& Sato-Bigbee, C. (2007). The immunomodulator FTY720 has a direct cytoprotective effect in oligodendrocyte progenitors. J Pharmacol Exp Ther, Vol.323, No.2, pp.626-635. 
Coelho, R.P.; Saini, H.S. \& Sato-Bigbee, C. (2010). Sphingosine-1-phosphate and oligodendrocytes: from cell development to the treatment of multiple sclerosis. Prostaglandins Other Lipid Mediat, Vol.91, No.3-4, pp.139-144.

Cutler, R.G.; Haughey, N.J.; Tammara, A.; McArthur, J.C.; Nath, A.; Reid, R.; Vargas, D.L.; Pardo, C.A. \& Mattson, M.P. (2004). Dysregulation of sphingolipid and sterol metabolism by ApoE4 in HIV dementia. Neurology, Vol.63, No.4, pp.626-630.

De Vito, W.J.; Xhaja, K. \& Stone, S. (2000). Prenatal alcohol exposure increases TNFalphainduced cytotoxicity in primary astrocytes. Alcohol, Vol.21, No.1, pp.63-71.

Ding, S. \& Schultz, P.G. (2004). A role for chemistry in stem cell biology. Nat Biotechnol, Vol.22, No.7, pp.833-840.

Ding, S.; Wu, T.Y.; Brinker, A.; Peters, E.C.; Hur, W.; Gray, N.S. \& Schultz, P.G. (2003). Synthetic small molecules that control stem cell fate. Proc Natl Acad Sci U $S$ A, Vol.100, No.13, pp.7632-7637.

Ding, V.M.; Ling, L.; Natarajan, S.; Yap, M.G.; Cool, S.M. \& Choo, A.B. (2010). FGF-2 modulates Wnt signaling in undifferentiated hESC and iPS cells through activated PI3-K/GSK3beta signaling. J Cell Physiol, Vol.225, No.2, pp.417-428.

Dinsmore, J.; Ratliff, J.; Deacon, T.; Pakzaban, P.; Jacoby, D.; Galpern, W. \& Isacson, O. (1996). Embryonic stem cells differentiated in vitro as a novel source of cells for transplantation. Cell Transplant, Vol.5, No.2, pp.131-143.

Doble, B.W. \& Woodgett, J.R. (2003). GSK-3: tricks of the trade for a multi-tasking kinase. J Cell Sci, Vol.116, No.Pt 7, pp.1175-1186.

Finkensieper, A.; Kieser, S.; Bekhite, M.M.; Richter, M.; Mueller, J.P.; Graebner, R.; Figulla, H.R.; Sauer, H. \& Wartenberg, M. (2010). The 5-lipoxygenase pathway regulates vasculogenesis in differentiating mouse embryonic stem cells. Cardiovasc Res, Vol.86, No.1, pp.37-44.

Fong, C.Y.; Gauthaman, K. \& Bongso, A. (2010). Teratomas from pluripotent stem cells: A clinical hurdle. J Cell Biochem.

Frebel, K. \& Wiese, S. (2006). Signalling molecules essential for neuronal survival and differentiation. Biochem Soc Trans, Vol.34, No.Pt 6, pp.1287-1290.

Fujikawa, T.; Oh, S.H.; Pi, L.; Hatch, H.M.; Shupe, T. \& Petersen, B.E. (2005). Teratoma formation leads to failure of treatment for type I diabetes using embryonic stem cell-derived insulin-producing cells. Am J Pathol, Vol.166, No.6, pp.1781-1791.

Funk, C.D. (2001). Prostaglandins and leukotrienes: advances in eicosanoid biology. Science, Vol.294, No.5548, pp.1871-1875.

Futerman, A.H. \& Hannun, Y.A. (2004). The complex life of simple sphingolipids. EMBO Rep, Vol.5, No.8, pp.777-782.

Futerman, A.H. \& Riezman, H. (2005). The ins and outs of sphingolipid synthesis. Trends Cell Biol, Vol.15, No.6, pp.312-318.

Gardell, S.E.; Dubin, A.E. \& Chun, J. (2006). Emerging medicinal roles for lysophospholipid signaling. Trends Mol Med, Vol.12, No.2, pp.65-75.

Gault, C.R.; Obeid, L.M. \& Hannun, Y.A. (2010). An overview of sphingolipid metabolism: from synthesis to breakdown. Adv Exp Med Biol, Vol.6881-23.

Gelineau-van Waes, J.; Starr, L.; Maddox, J.; Aleman, F.; Voss, K.A.; Wilberding, J. \& Riley, R.T. (2005). Maternal fumonisin exposure and risk for neural tube defects: mechanisms in an in vivo mouse model. Birth Defects Res A Clin Mol Teratol, Vol.73, No.7, pp.487-497.

Glaser, T.; Pollard, S.M.; Smith, A. \& Brustle, O. (2007). Tripotential differentiation of adherently expandable neural stem (NS) cells. PLoS One, Vol.2, No.3, pp.e298. 
Goessling, W.; North, T.E.; Loewer, S.; Lord, A.M.; Lee, S.; Stoick-Cooper, C.L.; Weidinger, G.; Puder, M.; Daley, G.Q.; Moon, R.T. \& Zon, L.I. (2009). Genetic interaction of PGE2 and Wnt signaling regulates developmental specification of stem cells and regeneration. Cell, Vol.136, No.6, pp.1136-1147.

Gofflot, F.; Hars, C.; Illien, F.; Chevy, F.; Wolf, C.; Picard, J.J. \& Roux, C. (2003). Molecular mechanisms underlying limb anomalies associated with cholesterol deficiency during gestation: implications of Hedgehog signaling. Hum Mol Genet, Vol.12, No.10, pp.1187-1198.

Goldman, J.E.; Hirano, M.; Yu, R.K. \& Seyfried, T.N. (1984). GD3 ganglioside is a glycolipid characteristic of immature neuroectodermal cells. J Neuroimmunol, Vol.7, No.2-3, pp.179-192.

Groszer, M.; Erickson, R.; Scripture-Adams, D.D.; Lesche, R.; Trumpp, A.; Zack, J.A.; Kornblum, H.I.; Liu, X. \& Wu, H. (2001). Negative regulation of neural stem/progenitor cell proliferation by the Pten tumor suppressor gene in vivo. Science, Vol.294, No.5549, pp.2186-2189.

Guan, K.; Chang, H.; Rolletschek, A. \& Wobus, A.M. (2001). Embryonic stem cell-derived neurogenesis. Retinoic acid induction and lineage selection of neuronal cells. Cell Tissue Res, Vol.305, No.2, pp.171-176.

Gulbins, E. \& Kolesnick, R. (2003). Raft ceramide in molecular medicine. Oncogene, Vol.22, No.45, pp.7070-7077.

Gutierrez, J. \& Brandan, E. (2010). A novel mechanism of sequestering fibroblast growth factor 2 by glypican in lipid rafts, allowing skeletal muscle differentiation. Mol Cell Biol, Vol.30, No.7, pp.1634-1649.

Guy, R.K. (2000). Inhibition of sonic hedgehog autoprocessing in cultured mammalian cells by sterol deprivation. Proc Natl Acad Sci U S A, Vol.97, No.13, pp.7307-7312.

Haegel, H.; Larue, L.; Ohsugi, M.; Fedorov, L.; Herrenknecht, K. \& Kemler, R. (1995). Lack of beta-catenin affects mouse development at gastrulation. Development, Vol.121, No.11, pp.3529-3537.

Haimovitz-Friedman, A.; Kolesnick, R.N. \& Fuks, Z. (1997). Ceramide signaling in apoptosis. Br Med Bull, Vol.53, No.3, pp.539-553.

Hait, N.C.; Allegood, J.; Maceyka, M.; Strub, G.M.; Harikumar, K.B.; Singh, S.K.; Luo, C.; Marmorstein, R.; Kordula, T.; Milstien, S. \& Spiegel, S. (2009). Regulation of histone acetylation in the nucleus by sphingosine-1-phosphate. Science, Vol.325, No.5945, pp.1254-1257.

Hait, N.C.; Oskeritzian, C.A.; Paugh, S.W.; Milstien, S. \& Spiegel, S. (2006). Sphingosine kinases, sphingosine 1-phosphate, apoptosis and diseases. Biochim Biophys Acta, Vol.1758, No.12, pp.2016-2026.

Hannun, Y.A.; Luberto, C. \& Argraves, K.M. (2001). Enzymes of sphingolipid metabolism: from modular to integrative signaling. Biochemistry, Vol.40, No.16, pp.4893-4903.

Hannun, Y.A. \& Obeid, L.M. (2002). The Ceramide-centric universe of lipid-mediated cell regulation: stress encounters of the lipid kind. J Biol Chem, Vol.277, No.29, pp.25847-25850.

Hannun, Y.A. \& Obeid, L.M. (2008). Principles of bioactive lipid signalling: lessons from sphingolipids. Nat Rev Mol Cell Biol, Vol.9, No.2, pp.139-150.

Harada, J.; Foley, M.; Moskowitz, M.A. \& Waeber, C. (2004). Sphingosine-1-phosphate induces proliferation and morphological changes of neural progenitor cells. $J$ Neurochem, Vol.88, No.4, pp.1026-1039. 
Hirabayashi, Y. \& Furuya, S. (2008). Roles of 1-serine and sphingolipid synthesis in brain development and neuronal survival. Prog Lipid Res, Vol.47, No.3, pp.188-203.

Hla, T.; Lee, M.J.; Ancellin, N.; Paik, J.H. \& Kluk, M.J. (2001). Lysophospholipids--receptor revelations. Science, Vol.294, No.5548, pp.1875-1878.

Hla, T.; Lee, M.J.; Ancellin, N.; Thangada, S.; Liu, C.H.; Kluk, M.; Chae, S.S. \& Wu, M.T. (2000). Sphingosine-1-phosphate signaling via the EDG-1 family of G-proteincoupled receptors. Ann N Y Acad Sci, Vol.90516-24.

Hu, B.Y.; Du, Z.W. \& Zhang, S.C. (2009). Differentiation of human oligodendrocytes from pluripotent stem cells. Nat Protoc, Vol.4, No.11, pp.1614-1622.

Hurst, J.H.; Mumaw, J.; Machacek, D.W.; Sturkie, C.; Callihan, P.; Stice, S.L. \& Hooks, S.B. (2008). Human neural progenitors express functional lysophospholipid receptors that regulate cell growth and morphology. BMC Neurosci, Vol.9118.

Ikeda, S.; Kishida, M.; Matsuura, Y.; Usui, H. \& Kikuchi, A. (2000). GSK-3beta-dependent phosphorylation of adenomatous polyposis coli gene product can be modulated by beta-catenin and protein phosphatase 2A complexed with Axin. Oncogene, Vol.19, No.4, pp.537-545.

Incardona, J.P. \& Roelink, H. (2000). The role of cholesterol in Shh signaling and teratogeninduced holoprosencephaly. Cell Mol Life Sci, Vol.57, No.12, pp.1709-1719.

Jana, A.; Hogan, E.L. \& Pahan, K. (2009). Ceramide and neurodegeneration: susceptibility of neurons and oligodendrocytes to cell damage and death. J Neurol Sci, Vol.278, No.1-2, pp.5-15.

Jana, A. \& Pahan, K. (2010). Fibrillar amyloid-beta-activated human astroglia kill primary human neurons via neutral sphingomyelinase: implications for Alzheimer's disease. J Neurosci, Vol.30, No.38, pp.12676-12689.

Jenkins, C.M.; Cedars, A. \& Gross, R.W. (2009). Eicosanoid signalling pathways in the heart. Cardiovasc Res, Vol.82, No.2, pp.240-249.

Jiang, P.; Selvaraj, V. \& Deng, W. (2010). Differentiation of embryonic stem cells into oligodendrocyte precursors. J Vis Exp, No.39, pp.

Jung, C.G.; Kim, H.J.; Miron, V.E.; Cook, S.; Kennedy, T.E.; Foster, C.A.; Antel, J.P. \& Soliven, B. (2007). Functional consequences of S1P receptor modulation in rat oligodendroglial lineage cells. Glia, Vol.55, No.16, pp.1656-1667.

Jung, J.U.; Ko, K.; Lee, D.H.; Chang, K.T. \& Choo, Y.K. (2009). The roles of glycosphingolipids in the proliferation and neural differentiation of mouse embryonic stem cells. Exp Mol Med, Vol.41, No.12, pp.935-945.

Kang, S.M.; Cho, M.S.; Seo, H.; Yoon, C.J.; Oh, S.K.; Choi, Y.M. \& Kim, D.W. (2007). Efficient induction of oligodendrocytes from human embryonic stem cells. Stem Cells, Vol.25, No.2, pp.419-424.

Karpen, H.E.; Bukowski, J.T.; Hughes, T.; Gratton, J.P.; Sessa, W.C. \& Gailani, M.R. (2001). The sonic hedgehog receptor patched associates with caveolin-1 in cholesterol-rich microdomains of the plasma membrane. J Biol Chem, Vol.276, No.22, pp.1950319511.

Kelley, R.L.; Roessler, E.; Hennekam, R.C.; Feldman, G.L.; Kosaki, K.; Jones, M.C.; Palumbos, J.C. \& Muenke, M. (1996). Holoprosencephaly in RSH/Smith-Lemli-Opitz syndrome: does abnormal cholesterol metabolism affect the function of Sonic Hedgehog? Am J Med Genet, Vol.66, No.4, pp.478-484.

Kelly, K.F.; Ng, D.Y.; Jayakumaran, G.; Wood, G.A.; Koide, H. \& Doble, B.W. (2011). betacatenin enhances Oct-4 activity and reinforces pluripotency through a TCFindependent mechanism. Cell Stem Cell, Vol.8, No.2, pp.214-227. 
Khanapure, S.P.; Garvey, D.S.; Janero, D.R. \& Letts, L.G. (2007). Eicosanoids in inflammation: biosynthesis, pharmacology, and therapeutic frontiers. Curr Top Med Chem, Vol.7, No.3, pp.311-340.

Kilkenny, D.M.; Rocheleau, J.V.; Price, J.; Reich, M.B. \& Miller, G.G. (2003). c-Src regulation of fibroblast growth factor-induced proliferation in murine embryonic fibroblasts. $J$ Biol Chem, Vol.278, No.19, pp.17448-17454.

Kim, M.H.; Lee, Y.J.; Kim, M.O.; Kim, J.S. \& Han, H.J. (2010). Effect of leukotriene D4 on mouse embryonic stem cell migration and proliferation: involvement of PI3K/Akt as well as GSK-3beta/beta-catenin signaling pathways. J Cell Biochem, Vol.111, No.3, pp.686-698.

Korkaya, H.; Paulson, A.; Charafe-Jauffret, E.; Ginestier, C.; Brown, M.; Dutcher, J.; Clouthier, S.G. \& Wicha, M.S. (2009). Regulation of mammary stem/progenitor cells by PTEN/Akt/beta-catenin signaling. PLoS Biol, Vol.7, No.6, pp.e1000121.

Kostenis, E. (2004). A glance at G-protein-coupled receptors for lipid mediators: a growing receptor family with remarkably diverse ligands. Pharmacol Ther, Vol.102, No.3, pp.243-257.

Krishnamurthy, K.; Wang, G.; Silva, J.; Condie, B.G. \& Bieberich, E. (2007). Ceramide Regulates Atypical PKC\{zeta $\} /\{$ lambda\}-mediated Cell Polarity in Primitive Ectoderm Cells: A NOVEL FUNCTION OF SPHINGOLIPIDS IN MORPHOGENESIS. J Biol Chem, Vol.282, No.5, pp.3379-3390.

Lambeau, G. \& Gelb, M.H. (2008). Biochemistry and physiology of mammalian secreted phospholipases A2. Annu Rev Biochem, Vol.77495-520.

Lanner, F. \& Rossant, J. (2010). The role of FGF/Erk signaling in pluripotent cells. Development, Vol.137, No.20, pp.3351-3360.

Layden, B.T.; Newman, M.; Chen, F.; Fisher, A. \& Lowe, W.L., Jr. (2010). G protein coupled receptors in embryonic stem cells: a role for Gs-alpha signaling. PLoS One, Vol.5, No.2, pp.e9105.

Lebman, D.A. \& Spiegel, S. (2008). Cross-talk at the crossroads of sphingosine-1-phosphate, growth factors, and cytokine signaling. J Lipid Res, Vol.49, No.7, pp.1388-1394.

Lee, A.S.; Tang, C.; Cao, F.; Xie, X.; van der Bogt, K.; Hwang, A.; Connolly, A.J.; Robbins, R.C. \& Wu, J.C. (2009). Effects of cell number on teratoma formation by human embryonic stem cells. Cell Cycle, Vol.8, No.16, pp.2608-2612.

Lee, C.W.; Choi, J.W. \& Chun, J. (2010a). Neurological S1P signaling as an emerging mechanism of action of oral FTY720 (Fingolimod) in multiple sclerosis. Arch Pharm Res, Vol.33, No.10, pp.1567-1574.

Lee, M.Y.; Ryu, J.M.; Lee, S.H.; Park, J.H. \& Han, H.J. (2010b). Lipid rafts play an important role for maintenance of embryonic stem cell self-renewal. J Lipid Res, Vol.51, No.8, pp.2082-2089.

Levental, I.; Grzybek, M. \& Simons, K. (2010). Greasing their way: lipid modifications determine protein association with membrane rafts. Biochemistry, Vol.49, No.30, pp.6305-6316.

Lewis, P.M.; Dunn, M.P.; McMahon, J.A.; Logan, M.; Martin, J.F.; St-Jacques, B. \& McMahon, A.P. (2001). Cholesterol modification of sonic hedgehog is required for long-range signaling activity and effective modulation of signaling by Ptc1. Cell, Vol.105, No.5, pp.599-612.

Li, J.; Wang, G.; Wang, C.; Zhao, Y.; Zhang, H.; Tan, Z.; Song, Z.; Ding, M. \& Deng, H. (2007). MEK/ERK signaling contributes to the maintenance of human embryonic stem cell self-renewal. Differentiation, Vol.75, No.4, pp.299-307. 
Li, Y.; Zhang, H.; Litingtung, Y. \& Chiang, C. (2006). Cholesterol modification restricts the spread of Shh gradient in the limb bud. Proc Natl Acad Sci U S A, Vol.103, No.17, pp.6548-6553.

Lin, M.E.; Herr, D.R. \& Chun, J. (2010). Lysophosphatidic acid (LPA) receptors: signaling properties and disease relevance. Prostaglandins Other Lipid Mediat, Vol.91, No.3-4, pp.130-138.

Lingwood, D. \& Simons, K. (2010). Lipid rafts as a membrane-organizing principle. Science, Vol.327, No.5961, pp.46-50.

Liour, S.S.; Kraemer, S.A.; Dinkins, M.B.; Su, C.Y.; Yanagisawa, M. \& Yu, R.K. (2006). Further characterization of embryonic stem cell-derived radial glial cells. Glia, Vol.53, No.1, pp.43-56.

Logan, C.M.; Giordano, A.; Puca, A. \& Cassone, M. (2007). Prostaglandin E2: at the crossroads between stem cell development, inflammation and cancer. Cancer Biol Ther, Vol.6, No.10, pp.1517-1520.

Luberto, C. \& Hannun, Y.A. (1999). Sphingolipid metabolism in the regulation of bioactive molecules. Lipids, Vol.34 SupplS5-11.

Lyssiotis, C.A.; Lairson, L.L.; Boitano, A.E.; Wurdak, H.; Zhu, S. \& Schultz, P.G. (2011). Chemical control of stem cell fate and developmental potential. Angew Chem Int Ed Engl, Vol.50, No.1, pp.200-242.

Marasas, W.F.; Riley, R.T.; Hendricks, K.A.; Stevens, V.L.; Sadler, T.W.; Gelineau-van Waes, J.; Missmer, S.A.; Cabrera, J.; Torres, O.; Gelderblom, W.C.; Allegood, J.; Martinez, C.; Maddox, J.; Miller, J.D.; Starr, L.; Sullards, M.C.; Roman, A.V.; Voss, K.A.; Wang, E. \& Merrill, A.H., Jr. (2004). Fumonisins disrupt sphingolipid metabolism, folate transport, and neural tube development in embryo culture and in vivo: a potential risk factor for human neural tube defects among populations consuming fumonisin-contaminated maize. J Nutr, Vol.134, No.4, pp.711-716.

Mayer-Proschel, M.; Kalyani, A.J.; Mujtaba, T. \& Rao, M.S. (1997). Isolation of lineagerestricted neuronal precursors from multipotent neuroepithelial stem cells. Neuron, Vol.19, No.4, pp.773-785.

Merrill, A.H., Jr.; Schmelz, E.M.; Dillehay, D.L.; Spiegel, S.; Shayman, J.A.; Schroeder, J.J.; Riley, R.T.; Voss, K.A. \& Wang, E. (1997). Sphingolipids--the enigmatic lipid class: biochemistry, physiology, and pathophysiology. Toxicol Appl Pharmacol, Vol.142, No.1, pp.208-225.

Meyer zu Heringdorf, D. \& Jakobs, K.H. (2007). Lysophospholipid receptors: signalling, pharmacology and regulation by lysophospholipid metabolism. Biochim Biophys Acta, Vol.1768, No.4, pp.923-940.

Miljan, E.A. \& Bremer, E.G. (2002). Regulation of growth factor receptors by gangliosides. Sci STKE, Vol.2002, No.160, pp.RE15.

Miron, V.E.; Jung, C.G.; Kim, H.J.; Kennedy, T.E.; Soliven, B. \& Antel, J.P. (2008a). FTY720 modulates human oligodendrocyte progenitor process extension and survival. Ann Neurol, Vol.63, No.1, pp.61-71.

Miron, V.E.; Schubart, A. \& Antel, J.P. (2008b). Central nervous system-directed effects of FTY720 (fingolimod). J Neurol Sci, Vol.274, No.1-2, pp.13-17.

Morales, A.; Lee, H.; Goni, F.M.; Kolesnick, R. \& Fernandez-Checa, J.C. (2007). Sphingolipids and cell death. Apoptosis, Vol.12, No.5, pp.923-939.

Mummery, C.L.; Feyen, A.; Freund, E. \& Shen, S. (1990). Characteristics of embryonic stem cell differentiation: a comparison with two embryonal carcinoma cell lines. Cell Differ Dev, Vol.30, No.3, pp.195-206. 
Murashov, A.K.; Pak, E.S.; Hendricks, W.A.; Owensby, J.P.; Sierpinski, P.L.; Tatko, L.M. \& Fletcher, P.L. (2005). Directed differentiation of embryonic stem cells into dorsal interneurons. Faseb J, Vol.19, No.2, pp.252-254.

Muscoli, C.; Doyle, T.; Dagostino, C.; Bryant, L.; Chen, Z.; Watkins, L.R.; Ryerse, J.; Bieberich, E.; Neumman, W. \& Salvemini, D. (2010). Counter-regulation of opioid analgesia by glial-derived bioactive sphingolipids. J Neurosci, Vol.30, No.46, pp.15400-15408.

Nakanaga, K.; Hama, K. \& Aoki, J. (2010). Autotaxin--an LPA producing enzyme with diverse functions. J Biochem, Vol.148, No.1, pp.13-24.

Napoli, K.L. (2000). The FTY720 story. Ther Drug Monit, Vol.22, No.1, pp.47-51.

Niwa, H.; Burdon, T.; Chambers, I. \& Smith, A. (1998). Self-renewal of pluripotent embryonic stem cells is mediated via activation of STAT3. Genes Dev, Vol.12, No.13, pp.2048-2060.

North, T.E.; Goessling, W.; Walkley, C.R.; Lengerke, C.; Kopani, K.R.; Lord, A.M.; Weber, G.J.; Bowman, T.V.; Jang, I.H.; Grosser, T.; Fitzgerald, G.A.; Daley, G.Q.; Orkin, S.H. \& Zon, L.I. (2007). Prostaglandin E2 regulates vertebrate haematopoietic stem cell homeostasis. Nature, Vol.447, No.7147, pp.1007-1011.

Ohanian, J. \& Ohanian, V. (2001). Sphingolipids in mammalian cell signalling. Cell Mol Life Sci, Vol.58, No.14, pp.2053-2068.

Okita, K. \& Yamanaka, S. (2006). Intracellular signaling pathways regulating pluripotency of embryonic stem cells. Curr Stem Cell Res Ther, Vol.1, No.1, pp.103-111.

Okudaira, S.; Yukiura, H. \& Aoki, J. (2010). Biological roles of lysophosphatidic acid signaling through its production by autotaxin. Biochimie, Vol.92, No.6, pp.698-706.

Osakada, F. \& Takahashi, M. (2011). Neural Induction and Patterning in Mammalian Pluripotent Stem Cells. CNS Neurol Disord Drug Targets.

Otaegi, G.; Yusta-Boyo, M.J.; Vergano-Vera, E.; Mendez-Gomez, H.R.; Carrera, A.C.; Abad, J.L.; Gonzalez, M.; de la Rosa, E.J.; Vicario-Abejon, C. \& de Pablo, F. (2006). Modulation of the PI 3-kinase-Akt signalling pathway by IGF-I and PTEN regulates the differentiation of neural stem/precursor cells. J Cell Sci, Vol.119, No.Pt 13, pp.2739-2748.

Paling, N.R.; Wheadon, H.; Bone, H.K. \& Welham, M.J. (2004). Regulation of embryonic stem cell self-renewal by phosphoinositide 3-kinase-dependent signaling. J Biol Chem, Vol.279, No.46, pp.48063-48070.

Pebay, A.; Bonder, C.S. \& Pitson, S.M. (2007). Stem cell regulation by lysophospholipids. Prostaglandins Other Lipid Mediat, Vol.84, No.3-4, pp.83-97.

Pebay, A.; Wong, R.C.; Pitson, S.M.; Wolvetang, E.J.; Peh, G.S.; Filipczyk, A.; Koh, K.L.; Tellis, I.; Nguyen, L.T. \& Pera, M.F. (2005). Essential roles of sphingosine-1phosphate and platelet-derived growth factor in the maintenance of human embryonic stem cells. Stem Cells, Vol.23, No.10, pp.1541-1548.

Pitson, S.M. \& Pebay, A. (2009). Regulation of stem cell pluripotency and neural differentiation by lysophospholipids. Neurosignals, Vol.17, No.4, pp.242-254.

Plachta, N.; Bibel, M.; Tucker, K.L. \& Barde, Y.A. (2004). Developmental potential of defined neural progenitors derived from mouse embryonic stem cells. Development, Vol.131, No.21, pp.5449-5456.

Plo, I.; Bettaieb, A.; Payrastre, B.; Mansat-De Mas, V.; Bordier, C.; Rousse, A.; KowalskiChauvel, A.; Laurent, G. \& Lautier, D. (1999). The phosphoinositide 3-kinase/Akt pathway is activated by daunorubicin in human acute myeloid leukemia cell lines. FEBS Lett, Vol.452, No.3, pp.150-154. 
Radeff-Huang, J.; Seasholtz, T.M.; Matteo, R.G. \& Brown, J.H. (2004). G protein mediated signaling pathways in lysophospholipid induced cell proliferation and survival. $J$ Cell Biochem, Vol.92, No.5, pp.949-966.

Resh, M.D. (2004). Membrane targeting of lipid modified signal transduction proteins. Subcell Biochem, Vol.37217-232.

Riboni, L.; Tettamanti, G. \& Viani, P. (2002). Ceramide in primary astrocytes from cerebellum: metabolism and role in cell proliferation. Cerebellum, Vol.1, No.2, pp.129-135.

Roy, S.; Plowman, S.; Rotblat, B.; Prior, I.A.; Muncke, C.; Grainger, S.; Parton, R.G.; Henis, Y.I.; Kloog, Y. \& Hancock, J.F. (2005). Individual palmitoyl residues serve distinct roles in H-ras trafficking, microlocalization, and signaling. Mol Cell Biol, Vol.25, No.15, pp.6722-6733.

Saini, H.S.; Coelho, R.P.; Goparaju, S.K.; Jolly, P.S.; Maceyka, M.; Spiegel, S. \& Sato-Bigbee, C. (2005). Novel role of sphingosine kinase 1 as a mediator of neurotrophin-3 action in oligodendrocyte progenitors. J Neurochem, Vol.95, No.5, pp.1298-1310.

Salli, U.; Fox, T.E.; Carkaci-Salli, N.; Sharma, A.; Robertson, G.P.; Kester, M. \& Vrana, K.E. (2009). Propagation of undifferentiated human embryonic stem cells with nanoliposomal ceramide. Stem Cells Dev, Vol.18, No.1, pp.55-65.

Samadi, N.; Bekele, R.; Capatos, D.; Venkatraman, G.; Sariahmetoglu, M. \& Brindley, D.N. (2011). Regulation of lysophosphatidate signaling by autotaxin and lipid phosphate phosphatases with respect to tumor progression, angiogenesis, metastasis and chemo-resistance. Biochimie, Vol.93, No.1, pp.61-70.

Sanchez, T. \& Hla, T. (2004). Structural and functional characteristics of S1P receptors. J Cell Biochem, Vol.92, No.5, pp.913-922.

Sato, N.; Meijer, L.; Skaltsounis, L.; Greengard, P. \& Brivanlou, A.H. (2004). Maintenance of pluripotency in human and mouse embryonic stem cells through activation of Wnt signaling by a pharmacological GSK-3-specific inhibitor. Nat Med, Vol.10, No.1, pp.55-63.

Satoi, H.; Tomimoto, H.; Ohtani, R.; Kitano, T.; Kondo, T.; Watanabe, M.; Oka, N.; Akiguchi, I.; Furuya, S.; Hirabayashi, Y. \& Okazaki, T. (2005). Astroglial expression of ceramide in Alzheimer's disease brains: a role during neuronal apoptosis. Neuroscience, Vol.130, No.3, pp.657-666.

Schuringa, J.J.; van der Schaaf, S.; Vellenga, E.; Eggen, B.J. \& Kruijer, W. (2002). LIF-induced STAT3 signaling in murine versus human embryonal carcinoma (EC) cells. Exp Cell Res, Vol.274, No.1, pp.119-129.

Spiegel, S. \& Kolesnick, R. (2002). Sphingosine 1-phosphate as a therapeutic agent. Leukemia, Vol.16, No.9, pp.1596-1602.

Spiegel, S. \& Milstien, S. (2003). Sphingosine-1-phosphate: an enigmatic signalling lipid. Nat Rev Mol Cell Biol, Vol.4, No.5, pp.397-407.

Storm, M.P.; Bone, H.K.; Beck, C.G.; Bourillot, P.Y.; Schreiber, V.; Damiano, T.; Nelson, A.; Savatier, P. \& Welham, M.J. (2007). Regulation of Nanog expression by phosphoinositide 3-kinase-dependent signaling in murine embryonic stem cells. $J$ Biol Chem, Vol.282, No.9, pp.6265-6273.

Strub, G.M.; Maceyka, M.; Hait, N.C.; Milstien, S. \& Spiegel, S. (2010). Extracellular and intracellular actions of sphingosine-1-phosphate. Adv Exp Med Biol, Vol.688141-155.

Strub, G.M.; Paillard, M.; Liang, J.; Gomez, L.; Allegood, J.C.; Hait, N.C.; Maceyka, M.; Price, M.M.; Chen, Q.; Simpson, D.C.; Kordula, T.; Milstien, S.; Lesnefsky, E.J. \& Spiegel, S. (2011). Sphingosine-1-phosphate produced by sphingosine kinase 2 in 
mitochondria interacts with prohibitin 2 to regulate complex IV assembly and respiration. FASEB J, Vol.25, No.2, pp.600-612.

Szefel, J.; Piotrowska, M.; Kruszewski, W.J.; Jankun, J.; Lysiak-Szydlowska, W. \& Skrzypczak-Jankun, E. (2011). Eicosanoids in prevention and management of diseases. Curr Mol Med, Vol.11, No.1, pp.13-25.

Takabe, K.; Paugh, S.W.; Milstien, S. \& Spiegel, S. (2008). "Inside-out" signaling of sphingosine-1-phosphate: therapeutic targets. Pharmacol Rev, Vol.60, No.2, pp.181195.

Takao, Y.; Yokota, T. \& Koide, H. (2007). Beta-catenin up-regulates Nanog expression through interaction with Oct-3/4 in embryonic stem cells. Biochem Biophys Res Commun, Vol.353, No.3, pp.699-705.

Tigyi, G. \& Parrill, A.L. (2003). Molecular mechanisms of lysophosphatidic acid action. Prog Lipid Res, Vol.42, No.6, pp.498-526.

Umehara, H.; Kimura, T.; Ohtsuka, S.; Nakamura, T.; Kitajima, K.; Ikawa, M.; Okabe, M.; Niwa, H. \& Nakano, T. (2007). Efficient derivation of embryonic stem cells by inhibition of glycogen synthase kinase-3. Stem Cells, Vol.25, No.11, pp.2705-2711.

van Noort, M.; Meeldijk, J.; van der Zee, R.; Destree, O. \& Clevers, H. (2002). Wnt signaling controls the phosphorylation status of beta-catenin. J Biol Chem, Vol.277, No.20, pp.17901-17905.

Vogel, G. (2005). Cell biology. Ready or not? Human ES cells head toward the clinic. Science, Vol.308, No.5728, pp.1534-1538.

Walter, D.H.; Rochwalsky, U.; Reinhold, J.; Seeger, F.; Aicher, A.; Urbich, C.; Spyridopoulos, I.; Chun, J.; Brinkmann, V.; Keul, P.; Levkau, B.; Zeiher, A.M.; Dimmeler, S. \& Haendeler, J. (2007). Sphingosine-1-phosphate stimulates the functional capacity of progenitor cells by activation of the CXCR4-dependent signaling pathway via the S1P3 receptor. Arterioscler Thromb Vasc Biol, Vol.27, No.2, pp.275-282.

Wang, G. \& Bieberich, E. (2010). Prenatal alcohol exposure triggers ceramide-induced apoptosis in neural crest-derived tissues concurrent with defective cranial development. Cell Death Dis, Vol.1, No.5, pp.e46.

Wang, G.; Krishnamurthy, K.; Chiang, Y.W.; Dasgupta, S. \& Bieberich, E. (2008a). Regulation of neural progenitor cell motility by ceramide and potential implications for mouse brain development. J Neurochem, Vol.106, No.2, pp.718-733.

Wang, G.; Krishnamurthy, K.; Umapathy, N.S.; Verin, A.D. \& Bieberich, E. (2009). The carboxyl-terminal domain of atypical protein kinase Czeta binds to ceramide and regulates junction formation in epithelial cells. J Biol Chem, Vol.284, No.21, pp.14469-14475.

Wang, G.; Silva, J.; Dasgupta, S. \& Bieberich, E. (2008b). Long-chain ceramide is elevated in presenilin 1 (PS1M146V) mouse brain and induces apoptosis in PS1 astrocytes. Glia, Vol.56, No.4, pp.449-456.

Wang, G.; Silva, J.; Krishnamurthy, K.; Tran, E.; Condie, B.G. \& Bieberich, E. (2005). Direct binding to ceramide activates protein kinase Czeta before the formation of a proapoptotic complex with PAR-4 in differentiating stem cells. J Biol Chem, Vol.280, No.28, pp.26415-26424.

Wang, N.K.; Tosi, J.; Kasanuki, J.M.; Chou, C.L.; Kong, J.; Parmalee, N.; Wert, K.J.; Allikmets, R.; Lai, C.C.; Chien, C.L.; Nagasaki, T.; Lin, C.S. \& Tsang, S.H. (2010). Transplantation of reprogrammed embryonic stem cells improves visual function in a mouse model for retinitis pigmentosa. Transplantation, Vol.89, No.8, pp.911919. 
Wong, R.C.; Tellis, I.; Jamshidi, P.; Pera, M. \& Pebay, A. (2007). Anti-apoptotic effect of sphingosine-1-phosphate and platelet-derived growth factor in human embryonic stem cells. Stem Cells Dev, Vol.16, No.6, pp.989-1001.

Wymann, M.P. \& Schneiter, R. (2008). Lipid signalling in disease. Nat Rev Mol Cell Biol, Vol.9, No.2, pp.162-176.

Xu, X.Q.; Graichen, R.; Soo, S.Y.; Balakrishnan, T.; Rahmat, S.N.; Sieh, S.; Tham, S.C.; Freund, C.; Moore, J.; Mummery, C.; Colman, A.; Zweigerdt, R. \& Davidson, B.P. (2008). Chemically defined medium supporting cardiomyocyte differentiation of human embryonic stem cells. Differentiation, Vol.76, No.9, pp.958-970.

Yanagisawa, M.; Liour, S.S. \& Yu, R.K. (2004a). Involvement of gangliosides in proliferation of immortalized neural progenitor cells. J Neurochem, Vol.91, No.4, pp.804-812.

Yanagisawa, M.; Nakamura, K. \& Taga, T. (2004b). Roles of lipid rafts in integrin-dependent adhesion and gp130 signalling pathway in mouse embryonic neural precursor cells. Genes Cells, Vol.9, No.9, pp.801-809.

Yanagisawa, M.; Nakamura, K. \& Taga, T. (2005). Glycosphingolipid synthesis inhibitor represses cytokine-induced activation of the Ras-MAPK pathway in embryonic neural precursor cells. J Biochem, Vol.138, No.3, pp.285-291.

Yanes, O.; Clark, J.; Wong, D.M.; Patti, G.J.; Sanchez-Ruiz, A.; Benton, H.P.; Trauger, S.A.; Desponts, C.; Ding, S. \& Siuzdak, G. (2010). Metabolic oxidation regulates embryonic stem cell differentiation. Nat Chem Biol, Vol.6, No.6, pp.411-417.

Ye, X.; Ishii, I.; Kingsbury, M.A. \& Chun, J. (2002). Lysophosphatidic acid as a novel cell survival/apoptotic factor. Biochim Biophys Acta, Vol.1585, No.2-3, pp.108-113.

Yun, S.P.; Lee, M.Y.; Ryu, J.M. \& Han, H.J. (2009). Interaction between PGE2 and EGF receptor through MAPKs in mouse embryonic stem cell proliferation. Cell Mol Life Sci, Vol.66, No.9, pp.1603-1616.

Zeng, X.; Cai, J.; Chen, J.; Luo, Y.; You, Z.B.; Fotter, E.; Wang, Y.; Harvey, B.; Miura, T.; Backman, C.; Chen, G.J.; Rao, M.S. \& Freed, W.J. (2004). Dopaminergic differentiation of human embryonic stem cells. Stem Cells, Vol.22, No.6, pp.925-940.

Zhang, P.; Andrianakos, R.; Yang, Y.; Liu, C. \& Lu, W. (2010). Kruppel-like factor 4 (Klf4) prevents embryonic stem (ES) cell differentiation by regulating Nanog gene expression. J Biol Chem, Vol.285, No.12, pp.9180-9189.

Zhu, S.; Wurdak, H. \& Schultz, P.G. (2010). Directed embryonic stem cell differentiation with small molecules. Future Med Chem, Vol.2, No.6, pp.965-973. 


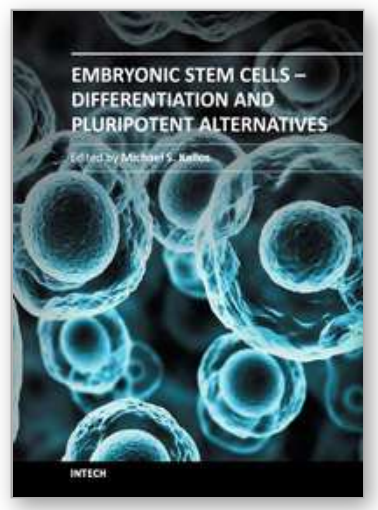

\author{
Embryonic Stem Cells - Differentiation and Pluripotent Alternatives \\ Edited by Prof. Michael S. Kallos
}

ISBN 978-953-307-632-4

Hard cover, 506 pages

Publisher InTech

Published online 12, October, 2011

Published in print edition October, 2011

The ultimate clinical implementation of embryonic stem cells will require methods and protocols to turn these unspecialized cells into the fully functioning cell types found in a wide variety of tissues and organs. In order to achieve this, it is necessary to clearly understand the signals and cues that direct embryonic stem cell differentiation. This book provides a snapshot of current research on the differentiation of embryonic stem cells to a wide variety of cell types, including neural, cardiac, endothelial, osteogenic, and hepatic cells. In addition, induced pluripotent stem cells and other pluripotent stem cell sources are described. The book will serve as a valuable resource for engineers, scientists, and clinicians as well as students in a wide range of disciplines.

\title{
How to reference
}

In order to correctly reference this scholarly work, feel free to copy and paste the following:

Erhard Bieberich and Guanghu Wang (2011). Bioactive Lipids in Stem Cell Differentiation, Embryonic Stem Cells - Differentiation and Pluripotent Alternatives, Prof. Michael S. Kallos (Ed.), ISBN: 978-953-307-632-4, InTech, Available from: http://www.intechopen.com/books/embryonic-stem-cells-differentiation-and-pluripotentalternatives/bioactive-lipids-in-stem-cell-differentiation

\section{INTECH}

open science | open minds

\section{InTech Europe}

University Campus STeP Ri

Slavka Krautzeka 83/A

51000 Rijeka, Croatia

Phone: +385 (51) 770447

Fax: +385 (51) 686166

www.intechopen.com

\section{InTech China}

Unit 405, Office Block, Hotel Equatorial Shanghai

No.65, Yan An Road (West), Shanghai, 200040, China

中国上海市延安西路65号上海国际贵都大饭店办公楼405单元

Phone: +86-21-62489820

Fax: +86-21-62489821 
(C) 2011 The Author(s). Licensee IntechOpen. This is an open access article distributed under the terms of the Creative Commons Attribution 3.0 License, which permits unrestricted use, distribution, and reproduction in any medium, provided the original work is properly cited. 